\title{
\ Kaupungin ja järjestökentän yhteistyö espoolaisen ruoka-avun kentällä koronakriisissä keväällä 2020: Näkökulmia vakiintuvaan ruoka-apuun
}

\begin{abstract}
Abstrakti
Tässä tutkimuksessa tarkastelemme espoolaista ruoka-apua koronakriisin aikana keväällä 2020 kaupungin ja järjestökentän toimijoiden välisen yhteistyön näkökulmasta. Tutkimuksen aineistona on toukokuussa 2020 kerätty kysely, joka kohdistettiin kaupungin poikkeusolojen ruokahuoltoryhmän jäsenille, ruoka-apujärjestöjen vastuuhenkilöille sekä ruoka-avun käytännön toteuttajille. Tulosten perusteella koronakriisi pakotti ruoka-apukentän äkillisiin muutoksiin, joista keskeisiä olivat toisaalta avun tarpeen kasvu, toisaalta sosiaalisen kanssakäymisen rajoitukset. Kriisin myötä yhteistyö kaupungin ja järjestöjen välillä tiivistyi. Käsityksissään eri toimijoiden rooleista ruoka-avun kentällä toimivat järjestöt ja kaupungin toimijat korostivat kumppanuutta jännitteiden sijaan. Keskeiset koronakriisin esiin tuomat muutostarpeet liittyvät yhteistyön vakiinnuttamiseen sekä ruoka-avun toimintatapojen kehittämiseen yhdenmukaisempaan suuntaan. Eri toimijat liittivät ruoka-avun hieman eri tavoin yhteiskunnalliseen arvokeskusteluun: Laajimmin yhteiskunnallisia epäkohtia ottivat esiin ruoka-avun käytännön toimijat. Kaupungin edustajien vastauksissa korostui välittäminen ja lainmukaisten tehtävien hoitaminen ja ruoka-apujärjestöjen vastuuhenkilöiden vastauksissa ruoka-avun vakiintumisen hyväksyntää heijastava auttamisen välttämättömyys. Tulokset haastavat niin kunta- kuin järjestösektorin toimijoita pohtimaan ruoka-avun tavoitteita ja järjestämisen tapoja sekä käyttämään hyväkseen ruoka-avusta saatavaa tietoa toimintansa kehittämisessä.
\end{abstract}

Avainsanat: ruoka-apu, koronakriisi, järjestöt, yhteistyö, kumppanuus 


\section{Johdanto}

Tässä tutkimuksessa tarkastelemme espoolaista ruoka-apua koronakriisin aikana keväällä 2020 kaupungin ja järjestökentän ${ }^{1}$ toimijoiden näkökulmasta. Tutkimuksen keskiössä on erityisesti vakiintuvan ruoka-avun kontekstissa tapahtuva kunnan ja järjestökentän yhteistyö, jota lähestymme toimijoiden roolien, toiminnan muutostarpeiden ja arvojen näkökulmasta. Ruoka-apu tarkoittaa ruoan jakamista vähävaraisille ja heikossa sosiaalisessa asemassa oleville henkilöille. Suomessa ruoka-apua jaetaan muun muassa Suomen evankelis-luterilaisen kirkon diakoniavastaanotoilla, niin sanotuissa leipäjonoissa ja ruokapankeissa sekä yhteisruokailutapahtumissa (Ohisalo ym., 2013).

Ruoka-avun merkitys korostuu kriiseissä. Yksilötasolla ruoka-avun tarvetta selittävät usein henkilökohtaiset kriisit. Ruoka-apua hakevat ovat keskimäärin hyvin pienituloisia ja kärsivät usein kasautuneesta huono-osaisuudesta, kuten samanaikaisista taloudellisista, terveydellisistä ja sosiaalisista ongelmista (Ohisalo, 2017). Myös yhteiskunnallisella tasolla ruoka-apu kytkeytyy kriiseihin, kun laajemmat talouden ja yhteiskunnan kriisit yleistävät yksilöiden henkilökohtaiset tragediat yhteiskunnallisiksi haasteiksi. Tämä näkyy ruoka-avun genealogiassa. Nykymuotoisen ruoka-avun synty paikantuu Suomessa 1990-luvun alun lamaan, jolloin voimakas talouden ja yhteiskunnan kriisi synnytti akuutin ruoka-avun tarpeen. Ruoka-avun volyymi laski hienoisesti 2000-luvulle tultaessa, mutta kasvoi taas 2008 globaalin taloudellisen taantuman seurauksena (Hiilamo, 2012). Viimeisin ruoka-avun merkitystä korostanut kriisi on keväällä 2020 puhjennut koronaviruspandemia. Esimerkiksi viimeisimmän sosiaalibarometrin mukaan koronakriisin myötä ruoka-avun tarve kasvoi (Sosiaalibarometri, 2020). Tässä mielessä ruoka-apu on sekä yksilön että yhteiskunnan näkökulmasta "hätäapua", jonka merkitys tulee näkyviin erityisesti kriiseissä.

Ruoka-apua on tutkittu paljon. Kansainvälisessä tutkimuksessa ruoka-apu kehystetään usein ruokaturvaan liittyväksi kysymykseksi (esim. Riches, 2002; Loopstra \& Tarasuk, 2012; 2015; Riches \& Silvasti, 2014). Suomalaista ruoka-apua on tutkittu runsaasti suhteessa pohjoismaiseen hyvinvointivaltioon (mm. Juntunen ym., 2006; Hiilamo, 2012; Silvasti, 2015; MacLeod, 2018). Lisäksi on tutkittu muun muassa ruoka-avusta käytyä julkista keskustelua (Karjalainen, 2008; Laihiala \& Ohisalo, 2017; Tikka, 2019) ja ruoka-avun saajia (Salonen ym., 2018; Alppivuori, 2021). 
Suomessa ruoka-apua on tarkasteltu aiemmissa tutkimuksissa suhteessa julkiseen sektoriin ja sosiaaliturvaan lähinnä niiden välisistä jännitteistä käsin. Ruoka-apu on tulkittu julkisen taloudellisen tuen turvaverkkojen läpi pudonneiden "viimeiksi luukuksi" ja pohjoismaisen hyvinvointivaltion epäonnistumiseksi (Iivari \& Karjalainen, 1999; Juntunen ym., 2006; Silvasti, 2011; Silvasti \& Karjalainen, 2014). Myös kansainvälisessä tutkimuskirjallisuudessa ruoka-apu on usein asemoitu jännitteiseen suhteeseen julkisen sektorin perusturvan kanssa (esim. Riches toim., 1997; Poppendieck, 1999; Loopstra \& Tarasuk, 2012; Riches \& Silvasti toim., 2014; MacLeod, 2018). Tästä kuvatusta lähtökohdasta käsin ruoka-apua on tarkasteltu tutkimuksissa ilmiönä, jota tutkimalla voidaan selvittää julkisen sosiaaliturvajärjestelmän aukkoja, ongelmia ja valuvikoja. Ruoka-apu on siis pitkään ollut tutkimuksellisesti ikään kuin virallisen auttamisjärjestelmän puutteiden peili. Samalla kun tällainen tutkimusasetelma on mahdollistanut monet tärkeät havainnot koskien hyvinvointiyhteiskunnan ongelmia, on se luonut myös tutkimuksellisen katvealueen: Kenties juuri tästä vastakohtaisuudesta ja jännitteisyydestä johtuen Suomessa ei ole toistaiseksi juuri tutkittu järjestökentän ja julkisen sektorin toimijoiden yhteistyötä ruoka-apukentällä.

Yhteistyön tutkiminen on ajankohtaista aikana, jona ruoka-apu vakiintuu ja etsii yhteiskunnallista paikkaansa. Tätä tarvetta kuvaa Sosiaali- ja terveysministeriön vastikään teettämä selvitys ruoka-avun toteuttamistavoista, rahoitusmekanismeista ja kuntien roolista (Karjalainen ym., 2021). Suomessa nykymuotoista ruoka-apua on jaettu 1990-luvun lamasta alkaen. Tuolloin vallalla oli laajalti käsitys, että ruoka-apu oli väliaikaista hätäapua akuutissa kriisissä ja sen tarve lakkaisi, kun yhteiskunnan ensisijaiset turvaverkot kykenisivät lamasta selvittyään jälleen huolehtimaan yhteiskunnan vähäosaisista. Näin ei kuitenkaan käynyt: Ruoka-aputoiminta ja avun tarve ovat jatkuneet jo kolmen vuosikymmenen ajan, ja ruoka-apu on vakiintunut osaksi suomalaista yhteiskuntaa (Karjalainen, 2000; Hiilamo, 2012; Silvasti, 2015). Vaikka ruoka-apua jaetaan laajasti eri puolilla maata, Suomessa ruoka-aputoiminta on pitkään ollut järjestäytymätöntä ruohonjuuritason toimintaa, jota kukin toimija on toteuttanut omalla tavallaan. Viime vuosina ruoka-avun kenttä on kuitenkin ollut muutoksessa hajanaisesta kohti vakiintuneempaa ja järjestäytyneempää toimintaa.

Ruoka-avun vakiintuminen viittaa prosessiin, jossa apu aletaan mieltää yhä kasvavassa määrin väliaikaisen hätäavun sijaan pysyväisluontoiseksi ja 
samalla myös yhteiskunnallisesti hyväksytyksi toimintatavaksi, mikä heijastuu avun järjestämisen tapoihin (Poppendieck, 1999). Suomessa ruoka-avusta on tullut paikallistasolla yhä ammattimaisempaa ja se on integroitunut apua tarjoavien yhteisöjen organisaatioiden toimintaan entistä tiiviimmin. Yhteiskunnallisella tasolla Suomessa ruoka-avun julkinen kuva on muuttunut (Karjalainen, 2008; Hiilamo, 2012:410; Tikka, 2019). Nykyään puhutaan yhä vähemmän ruoka-avun legitimiteetistä ja enemmän tarpeesta jakaa apua tehokkaasti, mikä kertoo ruoka-avun normalisoitumisesta suomalaisessa yhteiskunnallisessa keskustelussa (Silvasti, 2015). Myös ruoka-aputoiminnan sitominen entistä tiiviimmin osaksi hävikkiongelman ratkaisuyrityksiä voidaan nähdä yhteiskunnallisen vakiintumisen elementiksi (Salonen \& Silvasti, 2019).

Ruoka-avun vakiintuminen näkyy erityisesti laajenevissa kumppanuuksissa ja tiivistyvässä sektorien välisessä yhteistyössä. Kanadalaisen ruoka-apututkija Graham Richesin (2002:651-654) mukaan ruoka-avun vakiintumisprosessissa keskeistä on ensinnäkin apua tarjoavien järjestöjen keskinäisen yhteistyön, organisoitumisen ja yhteistoiminnan lisääntyminen, kun aiemmin itsenäisesti tahoillaan toimineet ruoka-avun jakajat alkavat koordinoida toimintaansa yhdessä ja muodostaa erilaisia yhteenliittymiä ja kattojärjestöjä. Toisena elementtinä on yhteistyö elintarvikejärjestelmän toimijoiden, kuten vähittäiskaupan ja elintarviketeollisuuden kanssa. Kolmantena elementtinä on yhteistyö julkisen sektorin kanssa ja sen tarjoama rahallinen tuki. Ruoka-aputoiminnan kehitys näyttää Suomessa mukailevan tätä kehitystä. Erilaiset ruoka-apuverkostot ovat yleistyneet paikallisesti ja enenevässä määrin myös kansallisesti. Ruoka-aputoiminnassa on havaittavissa lisääntyvää yhteistyötä elintarvikejärjestelmän toimijoiden kanssa. Julkinen sektori on mukana ruoka-aputoiminnassa yhä tiiviimmin esimerkiksi rahoittajana sekä kunnan, seurakuntien ja järjestöjen muodostamissa ruoka-apuverkostoissa.

Tässä artikkelissa paneudumme erityisesti kolmanteen vakiintumisen elementtiin, eli kaupungin ja ruoka-apua tarjoavien järjestöjen väliseen yhteistyöhön. Aiemman tutkimuksen perusteella ruoka-aputoimintaan liittyvä sektorien välinen yhteistyö kohtaa sekä mahdollisuuksia, että haasteita, jotka liittyvät 1) toimijoiden rooleihin, 2) käytännön toimintatapoihin ja 3) toimintaan liittyvään yhteiskunnalliseen ja arvokeskusteluun.

Ensinnäkin aiempi ruoka-apututkimus on korostanut ruoka-avun paikkaavaa ja vastakkaista roolia suhteessa julkiseen sektoriin (Iivari \& Karjalainen, 
1999; Juntunen ym., 2006). Esimerkiksi Sanna Lehtisen tutkimus seurakuntien ja julkisen sektorin yhteistyössä Euroopan sosiaalirahaston hankkeissa toi esiin kumppanuusnäkökulman: seurakunnat toimivat sosiaalisissa hankkeissa "julkisen sektorin apulaisina" ja "kansalaisyhteiskunnan talkoolaisina", jotka ne antoivat resurssejaan käyttöön yhteisiin projekteihin ja toimivat paikallisina verkostokumppaneina ja välittävinä instituutioina (Lehtinen, 2013). Kuntien ja seurakuntien yhteistyötä institutionaalisen vuorovaikutuksen näkökulmasta tarkastellussa tutkimuksessa Valdemar Kallunki havaitsi, että julkinen sektori oli keskeisessä asemassa yhteistyön onnistumisessa (Kallunki, 2010). Näistä tuloksista päätellen myös ruoka-apua jakavat seurakunnat ja järjestöt voivat olla tukevassa ja täydentävässä roolissa suhteessa julkiseen sektoriin sosiaalisen työn ja aineellisen avun kentällä. Toimiva yhteistyö ja roolijako edellyttävät kuitenkin keskinäistä neuvottelua ja tunnustamista.

Vertailu Suomen ulkopuolelle osoittaa, että ruoka-avun vakiintumisella ja siitä seuraavilla kumppanuuksilla on vaikutus ruoka-aputoiminnan käytännön toteuttamiseen. Uskonnon roolia ruoka-avussa tarkastelleessa vertailevassa tutkimuksessa kävi ilmi, että ruoka-avun institutionalisoituminen vaikutti niihin reunaehtoihin, joiden puitteissa ruoka-aputoimijat voivat tuoda esiin mahdollisia uskonnollisia elementtejä ruoka-aputoiminnan käytännöissä (Salonen, 2017b). Tulos viittaa siihen, että vakiintumisen myötä tiivistyvä yhteistyö homogenisoi ja karsii tiettyjä elementtejä ruoka-aputoiminnasta. Tässä tutkimuksessa tarkastelemme sitä, aiheuttavatko yhteistyöstä saadut kokemukset ruoan jakamisen käytäntöjen ja saamisen ehtojen aiempaa suurempaa yhdenmukaistamispainetta.

Yhtenä julkisen sektorin ja järjestöjen välisen yhteistyön potentiaalisena mahdollisuutena ja haasteena voidaan nähdä yhteiskunnallisen arvokeskustelun herättäminen. Lehtisen (2013) tutkimuksen mukaan seurakunnat toimivat Euroopan sosiaalirahaston hankkeissa julkisen sektorin käytännön kumppanin lisäksi myös arvokeskustelijoina, jotka kritisoivat yhteiskunnallisia epäkohtia ja heikossa asemassa olevien kansalaisten epäoikeudenmukaista kohtelua. Ruoka-aputoiminnassa tällainen yhteiskunnallinen arvokeskustelu on tarkoittanut julkisen sektorin tuki- ja palvelujärjestelmän aukkojen osoittamista ja järjestelmän puutteiden kritisoimista (Juntunen ym., 2006; Silvasti, 2015; Tikka, 2019). Tämä on tarkoittanut myös ruoka-aputoiminnan sisäistä kritiikkiä: ruokapankit ovat pankkeja, joita ei pitäisi olla. Tällaisen kritiikin esittäminen saattaa kuitenkin olla tiivistyvissä yhteistyösuhteissa haastavaa. 
Ruoka-avun muuttuessa kohti tiivistyvää yhteistyötä on tärkeää kysyä, miten ruoka-avun arvopohjaa muuttuvassa toimintaympäristössä sanoitetaan.

\section{Tutkimuksen toteutus}

Keväällä 2020 puhjennut koronaviruspandemia ja sen seuraukset on valittu tutkimuksen kontekstiksi, sillä poikkeukselliset tilanteet voivat tarjota tutkimukselle kahdenlaisia välineitä: Toisaalta ne avaavat näkökulman erityiseen, muuttuvaan ja rutiineja rikkovaan toimintaan, toisaalta ne paljastavat jotakin tavallisuudesta, rutiineista ja itsestäänselvyytenä pidetyistä asioista. Tämä pätee myös koronakriisiin ja ruoka-apuun. Koronakriisi paitsi johti muutoksiin ruoka-avun kentällä, myös herätti tarpeen ja avasi mahdollisuuden tutkia tätä kenttää tarkemmin.

Tutkimuksemme keskiössä on kunnan ja järjestökentän yhteistyö ruoka-avussa poikkeuksellisen yhteiskunnallisen kriisin ja vakiintuvan ruoka-avun aikana. Lähestymme aihetta edellä esitetyn keskustelun perusteella kolmesta näkökulmasta. Kysymme,

1. Kuinka eri toimijat kuvasivat omaa ja toistensa roolia ruoka-avussa koronakriisin aikana?

2. Minkälaisia muutostarpeita eri toimijat näkivät ruoka-apukentällä kriisistä opitun perusteella tulevaisuudessa?

3. Minkälaisia yhteiskunnallisiin arvoihin liittyviä näkökulmia eri toimijat nostivat esiin kuvatessaan kriisiajan ruoka-avusta oppimiaan asioita?

4. Yhdessä kysymykset valottavat vakiintuvaan ruoka-apuun ja sektorien väliseen yhteistyöhön liittyviä mahdollisuuksia, reunaehtoja ja haasteita ruoka-apukentällä toimivien tahojen itsensä sanoittamina.

Espoon ruoka-apukenttä on kiinnostava tapausesimerkki tutkimustehtävää koskien. Ruoka-avulla on Espoossa pitkät perinteet (kts. Alppivuori, 2019). Sen toteuttamisen nykymalli kuitenkin poikkeaa osin pääkaupunkiseudun muiden suurten kaupunkien toimintamallista. Espoossa ei ole hävikkiterminaalia tai vastaavaa ruoanjaon infrastruktuuriin liittyvää laajamittaista kaupungin ja järjestöjen yhteistyötä. Kaupunki jakaa ruoka-aputoimijoille järjestöavustuksia ja tarjoaa tiloja, mutta käytännön ruoka-aputyö on itsenäisten 
järjestöjen vastuulla, jotka kukin toteuttavat ruoka-apua parhaaksi näkemällään tavalla. Vuodesta 2018 alueella on kehitetty tiiviimpää espoolaista ruoka-avun mallia, joka perustuu verkostotoimintaan. Järjestöjen edustajat pitävät yhteyttä ja tekevät yhteistyötä Espoon ruoka-apuverkoston koordinaatioryhmässä, joka toteuttaa, kehittää ja koordinoi ruoka-aputoimintaan liittyviä kysymyksiä. Verkosto tarjoaa muun muassa koulutusta ja toimii kehittämiseen, käytännön kysymyksiin ja logistiikkaan liittyvän viestinnän kanavana. Verkoston vastuutahoina ovat Espoon diakoniasäätiö (Edistia) ja Espoon kaupunki.

Tutkimuksen aineistona on toukokuussa 2020 kerätty Webropol-työkalulla toteutettu kysely ( $=119)$. Kysely kohdistettiin espoolaisten ruoka-apujärjestöjen vastuuhenkilöille (jatkossa vastuuhenkilöt [V], N=14), käytännön toteuttajille eli ruoka-avussa toimiville vapaaehtoisille ja työhön kaupungin resurssipoolin kautta tulleille henkilöille (käytännön toteuttajat [K], N=93) sekä kaupungin poikkeusolojen ruokahuoltoryhmän jäsenille (ruokabuoltorybmän jäsenet $[\mathrm{R}], \mathrm{N}=12$ ). Vastaajaryhmille lähetettiin kullekin oma kyselynsä, jossa kartoitettiin ruoka-aputoimintaa ja sen muutoksia vastaajaryhmän mukaan hieman eri kysymyksin. Vastuuhenkilöiden ja ruokahuoltoryhmän jäsenten kyselyissä oli 19 kysymystä, joista kaikki olivat avoimia. Käytännön toteuttajien kyselyssä kysymyksiä oli 31, joista avoimia kysymyksiä oli 17. Vastausten pituudet vaihtelivat lyhyistä yksittäisistä virkkeistä yli kahdensadan sanan vastaukseen. Yhteensä vastauksia kertyi 115 sivua. Kohdejoukkojen koot eivät ole tarkkaan tiedossa, joten tarkkoja vastausprosentteja ei voida laskea. Arviomme mukaan ruokahuoltoryhmän jäsenistä kyselyyn vastasi noin puolet. Kahdessa ensimmäisessä ryhmässä vastaajien määrä suhteessa tutkimusjoukkoon on suurempi.

Tutkimuksen vastaajia pyydettiin arvioimaan koronakriisin merkitystä ruoka-aputoimintaan, vastaajan omaa tai tämän taustaorganisaation sekä muiden toimijoiden työtä ja rooleja ruoka-avun suunnittelussa, organisoinnissa, käynnistämisessä ja toteuttamisessa, toiminnan toteutumisen onnistumisia ja haasteita, kriisiajan ruoka-avun merkitystä, tulevaisuuden muutostarpeita ja kriisiajan toiminnasta opittuja asioita. Tulkitsemme vastaajien vastauksia paitsi kuvauksina toiminnasta, myös arvoarvostelmina ruoka-avun ja yhteiskunnan tilasta ja toivotusta tulevaisuuden kehityssuunnasta (Lambek, 2010; Sayer, 2011). Toisin sanoen analysoimme paitsi vastaajien näkemystä vallitsevasta tilanteesta, myös ruoka-apuun liitettyjä arvoja ja ihanteita. 
Aineistolähtöinen laadullinen tutkimusote sopii analyysimenetelmäksi silloin, kun aineistosta etsitään uutta, aiempaa ilmiötä koskevaa käsitystä haastavaa tai täydentävää tietoa (Alasuutari, 2011; Tuomi \& Sarajärvi, 2018). Analysoimme tutkimusaineistoa kahdessa vaiheessa, ensin avoimen induktiivisesti ja sitten tarkennettujen tutkimuskysymysten ohjaamana. Ensimmäisessä vaiheessa Kristiina Alppivuori analysoi keräämänsä tutkimusaineiston aineistolähtöisen sisällönanalyysin keinoin, keskittyen erityisesti aineiston pelkistämiseen ja ryhmittelyyn. Hän esitti yksityiskohtaisesti aineistosta esiin nousseet havainnot ja teemat eri toimijoiden näkökulmasta lomakkeiden kysymyksiin nojaten ja kirjoitti näiden tulosten pohjalta raportin (Alppivuori, 2020). Tämän jälkeen kirjoittajat keskustelivat ja jäsensivät aineistohavaintoja yhdessä pohtien tulosten yhtymäkohtia ajankohtaiseen suomalaiseen ja kansainväliseen ruoka-apuun liittyvään tutkimuskirjallisuuteen.

Jäsennyksessä keskeiseksi nousivat erityisesti aineistolähtöisen analyysin esiin tuoma järjestöjen ja julkisen sektorin yhteistyö osana ruoka-avun vakiintumista, sekä toisaalta aiemmissa tutkimuksissa toistunut ruoka-aputoiminnan jännitteisyys, erityisesti järjestöjen ja julkisen sektorin vastakkaisuus ja siihen sisältyvät arvokysymykset. Anna Sofia Salonen analysoi ja tulkitsi aineistoa ja siitä kertyneitä laadullisia tuloksia suhteuttaen vastaajien kokemuksia ja näkemyksiä ruoka-avun vakiintumisen, yhteistyön ja sektorirajojen jännitteiden johtoajatuksiin. Analyysiä ohjasivat yllä esitetyt tarkennetut tutkimuskysymykset. Salonen kirjoitti analyysin pohjalta tämän artikkelin hahmotelman, jonka pohjalta kirjoittajat vielä keskustelivat yhdessä tulosten eri tulkintamahdollisuuksista ja niiden esiin nostamista jatkokysymyksistä.

Seuraavissa luvuissa esittelemme analyysin keskeiset tulokset. Tulosten ymmärtämiseksi on tärkeää tarkastella sitä, kuinka koronakriisi vaikutti ruoka-avun toteuttamiseen Espoossa käytännössä. Ensimmäisessä tulosluvussa pureudumme tähän kysymykseen. Tämän jälkeen vastaamme kolmeen tutkimuskysymykseen analysoimalla eri toimijoiden kuvauksia omista ja toistensa rooleista ja kriisin esiin nostamista muutostarpeista sekä tarkastelemalla eri toimijoiden esiin nostamia yhteiskunnallisiin arvoihin liittyviä näkökulmia. Raportoimme tulokset tutkimuskysymyksittäin ja kunkin vastaajajoukon näkökulmasta. Keskitymme tulosten raportoinnissa vastaajaryhmien sisäisen ja ryhmien välisen laadullisen variaation ja samankaltaisuuksien esiin tuomiseen. Suorissa lainauksissa vastaajiin on viitattu vastaajaryhmän sekä kysymykseen ja vastaajaan viittaavalla järjestysnumerolla. Johtopäätösosiossa 
arvioimme tutkimuksen rajoituksia, havaintojen yhteiskunnallista merkitystä ja jatkotutkimustarpeita.

\section{Ruoka-apu kriisissä}

Kuten muuallakin Suomessa, Espoossa ruoka-avun tarve kasvoi keväällä 2020 koronapandemian myötä. Ruoka-avun piiriin hakeutui tuolloin paitsi apua jo aiemmin tarvinneita ihmisiä, myös uusia, lomautusten ja työttömyyden vuoksi akuutteja taloudellisia vaikeuksia kohdanneita avun tarvitsijoita. Avuntarpeen muutoksen lisäksi ruoka-aputoimintaan vaikuttivat pandemian leviämisen ehkäisemiseksi asetetut kokoontumisrajoitukset, karanteenisuositukset ja sosiaalisen etäisyyden periaate. Pandemiarajoitusten myötä osa järjestöistä lopetti toimintansa tilapäisesti. Näille järjestöille aiemmin toimitettu avustusruoka ohjautui muille järjestöille. Toisilla järjestöillä avuntarve ja ruoanjakovolyymi kasvoivat, kun toiminnan pysäyttäneiden järjestöjen asiakkaita ohjautui heidän palvelunsa piiriin samalla, kun ruoka-apua tarvitsivat uudet asiakasryhmät.

Samaan aikaan yhteiskunnallisen kriisin aikaansaaman avun tarpeen kasvun kanssa ruoka-aputoiminta siis itsessään kriisiytyi, kun toimijoiden oli lyhyellä varoitusajalla otettava käyttöön uudenlaisia hygieniaan liittyviä käytäntöjä ja mukautettava toimintansa rajoitusten puitteisiin. Kaikki kasvokkain tapahtunut vapaaehtoistyö sekä yhteisölliset toiminnot lopetettiin. Järjestön vastuuhenkilö kuvasi tätä omien sanojensa mukaan radikaalia muutosta: "Meille on ominaista asiakkaan kohtaaminen, vahva yhteisöllisyys ja monet pienet yhteisölliset ryhmämme. Nyt tämä kaikki jouduttiin jättämään ja tilalle jäi pelkkä persoonaton ruokakassi” (V2.6).

Rajoitukset pakottivat muuttamaan ruoka-avun jakamisen tapoja. Asiakkaan itse valitsemien tuotteiden sijaan siirryttiin valmiiden ruokakassien jakoon. Jonomuotoisesta ruoanjaosta siirryttiin ajanvaraukseen tai palvelemaan asiakkaita yksi kerrallaan muiden odottaessa ulkona. Riskiryhmien auttaminen vaati omat erityisjärjestelynsä. Lisäksi iäkkäät ja riskiryhmiin kuuluvat vapaaehtoistyöntekijät joutuivat jäämään pois avustustoiminnasta, mikä aiheutti henkilöstövajausta.

Kaupungin kannalta keskeistä koronakriisissä oli huolehtia huoltovarmuudesta sekä riskiryhmien ja karanteeniin määrättyjen ruokahuollosta. Espoon kaupungin poikkeusolojen ruokahuoltoryhmän tehtäväksi tuli sel- 
vittää, miten ruokahuolto toteutettaisiin ja huoltovarmuus taattaisiin kriisitilanteessa. Kaupunki välitti resurssipoolinsa kautta lisähenkilökuntaa ruoka-apujärjestöihin kirjastoista ja varhaiskasvatuksesta. Lisäksi perustettiin ruokahuollon neuvontanumero, jossa sosiaalipalveluiden työntekijät vastasivat asiakkaiden puheluihin ja selvittivät avun tarvetta. Ruokahuollon sähköposti toimi tiedonvälityksen välineenä sosiaalityöstä ruokahuollon logistiikkaan sekä järjestöihin.

Kaupunki perusti oman väliaikaisen koronakriisin ruoka-avun logistiikkakeskuksen, joka huolehti ruoan tilaamisesta ja jakelusta karanteenissa oleville kuntalaisille. Lisäksi kaupunki tilasi yhdeltä paikallisista järjestöistä palvelun, jonka ajatuksena oli kuljettaa ruokaostoksia kotiin karanteenissa oleville ja yli 70-vuotiaille vapaaehtoisverkoston turvin. Kaupungin ruoka-apupalvelujen tarve jäi kuitenkin melko pieneksi. Toiminnan kuluessa havaittiin, että ruoka-avun tarve kaupungin käynnistämissä toiminnoissa oli pienempi kuin oli kuviteltu. Sen sijaan kaupungin toimijat havaitsivat muita palvelutarpeita. Ruokahuoltoryhmän jäsenen sanoin: "ruoka-avun neuvonnassa pystyttiin ohjaamaan asiakkaita oikeisiin palveluihin, koska huomattiin, että avuntarve oli monesti muussa kuin ruoka-avussa" (R13.7). Kaupungin ruoka-aputoiminnoissa korostui siis aineellisen avun sijaan ohjaustoiminta, jossa asiakkaita voitiin ohjata oikeiden palveluiden piiriin.

Kriisin aikana järjestöjen ja kaupungin välinen yhteistyö tiivistyi. Konkreettinen yhteistyön paikka oli Espoon ruoka-apuverkosto. Koronakriisi lisäsi ruoka-apuverkoston työtä ja toimintapainetta. Verkoston vastuuhenkilön työtä allokoitiin entistä enemmän verkostotyöhön muiden työtehtävien sijaan, jotta saatiin resursseja tukea järjestöjä, ylläpitää yhteistyötä ja rakentaa kriisiajan toimintamalleja. Kaiken kaikkiaan koronakriisin mukanaan tuomat muutokset ja rajoitukset pakottivat Espoon ruoka-apukenttää muuttamaan ruoka-avun toimintatapoja ja arvioimaan uudelleen järjestökentän ja kaupungin toimijoiden välisiä suhteita ja vastuita.

\section{Näkemykset eri toimijoiden rooleista ruoka-aputoiminnassa}

Aiempi ruoka-apuun liittyvä tutkimus on korostanut ruoka-apua jakavien toimijoiden julkisen sektorin puutteita paikkaavaa roolia (Iivari \& Karjalainen, 1999; Juntunen ym., 2006). Tässä tutkimuksessa toimijat itse sanoittivat toistensa roolia vastakkaisuuden ja paikkaavuuden sijaan kumppanuuksien 
kautta. Sekä järjestöjen vastuuhenkilöillä, että kaupungin ruokahuoltoryhmän edustajilla oli melko yhtenevät käsitykset järjestöjen ja seurakuntien roolista ruoka-apuun liittyvässä yhteistyössä. Kumpikin taho korosti yhteistyön merkitystä eikä tuonut esiin erityisiä jännitteitä.Järjestöt ja seurakunnat nähtiin yhteistyössä ennen kaikkea ketterinä ja mukautumiskykyisinä kumppaneina, joilla oli hyödyllisiä resursseja. Kaupungin ruokahuoltoryhmän jäsenet näkivät järjestöt ja seurakunnat asiakaskunnalle tuttuina matalan kynnyksen avuntarjoajina, valmiiden asiakassegmenttien ja vapaaehtoisten varantona, käytännön ruoka-aputyön toteuttajina, tiedon välittäjinä sekä yhteistyökumppaneina suunnittelutyössä. Ruokahuoltoryhmän jäsen kuvasi järjestöjen roolia: "Käytännön toteutus hävikkiruoka-avun toteuttamisessa on ollut järjestöillä, jotka toimineet ns. etulinjassa ketterästi kriisin keskellä ja joita kaupunki tukenut" (R8.8).

Järjestöjen vastuuhenkilöt taas kuvasivat edustamiensa järjestöjen roolia yhteistyökumppaneiksi ja toimijoiksi muiden rinnalla. Järjestöt nähtiin myös resurssi- ja suhdevarantona, jotka osallistuivat toimintaan tilojensa, verkostojensa, vapaaehtoistensa ja asiakkaidensa kautta. Järjestöjä luonnehdittiin ketteriksi toimijoiksi suhteessa kaupunkiin:

Meillä oli valmiit toimivat resurssit (kaupat, joista saamme hävikkitavaraa), tilat sekä yhteydet toinen toisiimme. Kaupunki isona toimijana on paljon hitaammin kääntyvä laiva. Muuntauduimme koko ajan ja venyimme uusiin ulottuvuuksiin! (V9.6.)

Kuvauksissa kaupungin roolista ja merkityksestä eri järjestöjen vastuuhenkilöiden ja kaupungin ruokahuoltoryhmän jäsenten näkemykset erosivat hieman toisistaan. Järjestöjen vastuuhenkilöt kuvasivat kaupungin roolia resurssien tarjoajaksi. Vastausten perusteella kaupungin tarjoama työntekijäresurssi oli koronakriisin aikana merkittävä. Lisäksi kaupunki tarjosi joillekin järjestöille ruoka- ja laiteresursseja sekä tila- ja tarjoiluresursseja verkostotapaamisten järjestämiseen. Asiakasrajapinnassa kaupungin rooliksi nähtiin asiakkaiden pyyntöihin vastaaminen, tarpeiden kartoittaminen ja ruoka-avun piiriin ohjaaminen. Kaupunkia kuvattiin arvostavaksi ja järjestön vastuuhenkilön sanoin "kokoonsa nähden dynaamiseksi" yhteistyökumppaniksi (V11.13). Toisaalta kaupungilta olisi toivottu vielä nopeampaa reagointia erityisesti koronakriisin alkuvaiheessa. 
Yhteistyö ei kuitenkaan ollut tasaveroista kaupungin ja järjestöjen kesken, vaan kaupungin rooli oli myös toimia päättävänä tahona, joka määritti mahdollisia ruoka-apuun liittyvän yhteistyön toteutustapoja ja osoitti siten toiminnan rajoja. Merkillepantavaa on myös, että kokemus kaupungin roolista ja merkityksestä vaihteli järjestöjä edustaneiden vastaajien kesken: Toisten mielestä rooli oli välttämätön tai tärkeä, toisten mukaan taas vähäinen. Eräs vastuuhenkilö esimerkiksi totesi, että pieniä rahallisia avustuksia ja ruokalahjoituksia lukuun ottamatta "Kaupungilla ei ole käytännössä ollut roolia työmme suunnittelussa, organisoinnissa, käynnistämisessä tai toteuttamisessa"(V11.3).

Kaupungin ruokahuoltoryhmän jäsenet puolestaan kuvasivat kaupungin roolia muun muassa koordinoijan, yhteen saattajan, tukijan ja mahdollistajan termein. Lisäksi kaupunkia luonnehdittiin palveluiden tilaajaksi ja informoijaksi, sekä resurssien tarjoajaksi: kaupunki antoi järjestöille henkilöresursseja ja toimitti ruokaa edelleen jaettavaksi. Erään ruokahuoltoryhmän jäsenen mukaan kaupungilla oli

suuri rooli, koska kaupunki järjesti oman ruoka-aputoiminnon tukemaan järjestöjen kautta saatavaa ruoka-apua. Kaupungin ruoka-aputoiminto on myös toimittanut merkittäviä määriä ruokaa järjestöille edelleen jaettavaksi. Työvoima toimintaan saatiin kaupungin resurssipoolista. (R6.7.)

Kaupungin edustajien näkemyksissä tuli ilmi myös kaupungin vastuullisuus kuntalaisista lain nojalla, sekä toisaalta pyrkimys myös näyttäytyä vastuullisena toimijana. Ruokahuoltoryhmän jäsen toteaa karanteenikassipalveluun liittyen: "Oli varmaan hyvä, että kaupunki ryhtyi tähän, vaikka kysyntä ei ollut kovin suuri. Mutta ainakin näytimme, että haluamme tukea ja auttaa meidän asukkaita."(R6.10.)

Painotuseroja kaupungin roolissa ja merkityksessä järjestöjen kesken ja verrattuna kaupungin edustajien näkemykseen selittänee se, että eri järjestöt olivat eriävässä määrin suoraan yhteistyössä kaupungin kanssa esimerkiksi ruokalahjoitusten osalta. Epäsymmetrisyys kaupungin ja järjestökentän näkökulmasta tulee esiin lisäksi juuri kaupungin erityisaseman ja lainsäädännön luomien velvollisuuksien näkökulmasta. Kaupunki sekä asettaa järjestökentän toiminnalle reunaehtoja, että kantaa lain nojalla viimesijaista vastuuta kuntalaisista. Tällaisena vastuullisena toimijana kaupunki haluaa myös profiloitua ruoka-aputoiminnan kautta. 
Myös ruoka-avun käytännön toimijat kuvasivat kaupungin roolia kertoessaan yhteistyön käytännön haasteista ja onnistumisista. Osa vastaajista katsoi, että yhteistyö kaupungin ja järjestöjen kesken oli toimivaa, suvaitsevaa ja yhteistyöhaluista. Jonkin verran erimielisyyttä tai väärinkäsityksiä oli ruoka-avun kriteereistä. Myös tiedotuksessa olisi käytännön toimijoiden mukaan ollut tarkennettavaa ja yhdenmukaistettavaa. Yhteistyöhaasteita aiheuttivat myös kaupungin ja järjestöjen töiden erilaisuus sekä kaupungin toimintaa ohjaavat lainsäädännölliset normit.

Kaupungin ja järjestöjen edustajat jakoivat keskenään melko samanlaiset käsitykset ruoka-apuverkoston roolista. Järjestöjen vastuuhenkilöt näkivät ruoka-apuverkoston roolin olleen koronakriisissä välittävä: verkosto on yhteistyön, yhteydenpidon ja verkostoitumisen mahdollistaja, tiivistäjä ja ylläpitäjä, tuttuuden, kokemusten vaihdon, jakamisen, linjavedon ja tehokkuuden sekä kokonaiskuvan ja vastavuoroisen auttamisen mahdollistaja ja tuen ja inspiraation lähde. Myös kaupungin ruokahuoltoryhmän jäsenet näkivät verkostolla olevan saman välittävän rooliin kuin suuri osa järjestöjen edustajia: verkoston on kokonaisuudesta huolehtija, yhteistyön ja toimintatapojen yhteensovittamisen väline ja tiedonkulun kanava. Lisäksi kaupungin edustajien taholta tunnustettiin verkoston taustalla oleva mittava pohjatyö, joka mahdollisti onnistumisen kriisiin vastaamisessa. Esimerkiksi erään kaupungin ruokahuoltoryhmän vastaajan mukaan

Järjestöjen olemassa olevalla verkostolla ja yhteistyökäytännöillä on ollut varmasti iso merkitys siinä, että poikkeusoloissa ruoka-apu on saatu toimimaan näin hyvin järjestöjen päässä [...] On ollut jo olemassa oleva verkosto, jossa tieto kulkee järjestöjen välillä sekä kaupungin suuntaan. Ei ole tarvinnut lähteä kartoittamaan, mitä ja kuka tekee Espoossa. (R7.8.)

Verkoston merkityksen korostus kuitenkin jakoi järjestöjä edustaneita vastaajia. Jotkut vastaajat korostivat verkoston tukevaa, kannustavaa ja toimintaa vahvistavaa roolia. "Yhdessä olemme enemmän kuin yksin", kuten eräs vastuuhenkilö totesi (V10.1). Jotkut taas pitivät verkoston roolia vähäisenä. Yksi vastuuhenkilö esimerkiksi totesi, että verkosto saattoi hyvinkin olla hyödyllinen joillekin muille järjestöille, mutta heidän toiminnassaan se oli sivuroolissa. Toinen vastuuhenkilö puolestaan vastasi kysymykseen verkoston roolista: "Ei suurta merkitystä. Teimme samaa työtä jo ennen kriisiä." (10.3.) 


\section{Kohti yhteistyötä, kohti yhdenmukaisuutta}

Aiemman tutkimuksen perusteella ruoka-avun vakiintuminen ja siitä seuraavat kumppanuudet vaikuttavat ruoka-aputoiminnan käytännön toteuttamiseen yhdenmukaistamalla toimintaa (Salonen, 2017b). Huomio on yhteneväinen tämän tutkimuksen havaintojen kanssa. Tutkimuksen vastaajat kuvasivat, mitä he oppivat ruoka-aputoiminnasta koronakriisin aikana ja millaisia muutostarpeita kriisi toi esiin. Näissä vastauksissa keskeiseksi nousivat erityisesti tiivistyvä yhteistyö, sekä yhdenmukaistuvat avun jakamisen käytännöt.

Yhteistyön merkitys nousi esiin kaikissa vastaajaryhmissä. Kaupungin ruokahuoltoryhmän vastaajille koronakriisi oli opettanut verkostojen ja uuden kokeilemisen merkityksestä. Lisäksi he korostivat varautumista ja peräänkuuluttivat vastuunjaon määrittelyn tärkeyttä. Eräs heistä vastasi:

Minusta meidän kannattaisi laatia tämän kokemuksen pohjalta varautumissuunnitelma, jossa on määritelty eri toimijoiden vastuut. Olisi hyvä olla helposti tiedossa toimijat, joita ruoka-avun pystyttämisessä tarvitaan, käytännön prosesseja olisi hyvä miettiä etukäteen. (R18.11.)

Myös järjestöjen vastuuhenkilöt toivat esiin yhteistyön jatkamisen ja ylläpitämisen tarpeellisuuden. He peräänkuuluttivat tiiviimpää yhteistyötä ja suurempaa tukea kaupungilta. Yksi vastuuhenkilö totesi:

Kun kriisi todetaan, niin kaupungin ja järjestöjen, seurakuntien pitää reagoida heti. Istua alas ja miettiä kuka ottaa "kopin" minkin asian hoitamisessa. Vuoropuhelua on sitten jatkettava tiiviisti yhteisten tavoitteiden mukaan. Kaupungin tehtävä on myös varmistaa, että jos järjestöt toimiakseen tarvitsevat pientä apua taloudellisesti toimiakseen paremmin, niin se apu tulee saada nopeasti. (V18.2.)

Kaupungin panos yhteistyöhön olisi vastaajien mukaan järkevää myös kustannussyistä. Eräs vastuuhenkilö totesi, että ruoka-apua jakavilla järjestöillä on monenlaisia resursseja: "Järjestöissä on vahvaa osaamista, sitoutumista, dynaamisuutta ja sitkeyttä - kolmannen sektorin tuoma hyöty kuntalaisille ja kaupungille on todella kustannustehokasta”(18.13). 
Ruoka-avun käytännön toteuttajat nostivat esiin sekä yhteistyön onnistumisia, että kehittämistarpeita. Vastauksissa kiitettiin toimivaa yhteistyötä ja moitittiin mahdollisia henkilöiden välisiä kitkoja. Vastaajat pitivät yhteisistä pelisäännöistä sopimista ja kiinnipitämistä ruoka-avun käytännön toteuttamisessa tärkeänä. He esittivät toiveen, että kaupungilla olisi avoimempi ja selkeämpi linjaus ruoka-aputoimintaan liittyen, että avun saamisen kynnystä madallettaisiin ja että ruoka-avun saamisen ehtoja kevennettäisiin. Lisäksi käytännön toimintaa toteuttavat henkilöt toivoivat kaupungin osallistuvan toiminnan kustannuksiin.

Yksi konkreettinen tiivistyvän yhteistyön muoto voisi vastausten perusteella olla hävikkiterminaalin tai logistiikkakeskuksen perustaminen. Kaupungin ruokahuoltoryhmän vastaaja totesi:

Yhteisen logistiikkakeskuksen perustaminen on ollut puheissa vuosia, mutta se ei ole toteutunut. Sellaisen perustamiselle voisi olla tarvetta, koska silloin toimintaa pystyttäisiin koordinoimaan selkeästi. (R18.2.)

Myös järjestöjen vastuuhenkilöiden vastauksissa nousi esiin tarve logistiikkakeskukselle tai ruokaterminaalille. Erään vastuuhenkilön mukaan

Minusta ruoka-aputoiminta Espoossa tulisi järjestää ruokaterminaalin kautta niin, että jakopisteitä olisi ympäri Espoon kaupunkikeskuksia ja niin, että kaikissa jakopisteissä riittäisi ruokaa jaettavaksi arvioidun tarpeen mukaan. Ruoan hakijoita tulisi rohkaista käymään oman lähialueensa jakopisteissä. Tätä ehkä yritimme nyt koronakriisin aikana tukea ja juurruttaa.(V17.7.)

Järjestöjen edustajien vastauksissa nostettiin esiin, että kaupungin tulisi olla keskeisemmin mukana hävikin tunnistamisessa, hyödyntämisessä ja hyötykäytön organisoimisessa pääkaupunkiseudun muiden suurten kaupunkien esimerkin mukaisesti. Logistiikkakeskus olisi tapa toteuttaa tätä.

Toisaalta järjestöjen vastuuhenkilöiden vastauksissa nousi esiin myös näkökulmia, joissa yhteistyö ei joko ottanut haluttua muotoa tai ei vastannut tarvetta. Vastuuhenkilö kertoo:

Itse odotin kovasti, että olisi saatu nopeasti jokin yhteistyökuvio niin, että puhelut olisi ohjattu kaupungille ja me olisimme toimittaneet ruoka-avun 
sitä kautta. Näin ei kuitenkaan käynyt. Keskityimme toimimaan mahdollisimman hyvin omassa toimipaikassamme ja omassa foorumissamme. (V4.6.)

Kun vastaajan toivoma yhteistyömuoto ei toteutunut, hänen yhdistyksensä päätti keskittyä oman toimintansa itsenäiseen vahvistamiseen. Sama vastaaja kertoo myös toisesta tapauksesta:

Jossain vaiheessa heitettiin ajatus, että kaupunki avaa ison logistiikkakeskuksen, johon me mahdollisesti tulisimme toimimaan mukaan. Kun paria mahdollista paikkaa käytiin katsomassa, me totesimme osaltamme, että meillä on itsellämme ihan vastaavat kylmätilat. Muutto ei siis olisi kannattanut. Saimme rauhoittua toimimaan omassa tutussa tilassa. (V4.6.)

Yhteistyöhön liittyvät odotukset ja toteutumisen käytännöt eivät siis aina vastanneet toisiaan. Haastateltavan vastauksesta huokuu toive saada tehdä omaa työtä tutuissa puitteissa ja hyväksi koetuin toimintatavoin.

Yhteistyöhön liittyvien kysymysten lisäksi järjestöjen edustajat ja ruoka-avun käytännön toteuttajat nostivat esiin avustustyön käytännön järjestämiseen liittyviä kysymyksiä. Ruoka-avun jakamiseen liittyvien käytäntöjen muutostarpeissa nousivat esiin asiakaskunnan hallinta ja itse avustuksen muoto, joita tarkasteltiin tehokkuutta, valinnanvapautta ja asiakkaiden kokemuksia painottavista näkökulmista. Koronapandemian vuoksi joissakin ruoka-apupaikoissa käyttöön otettu ennakkoilmoittautuminen nähtiin toimivaksi ratkaisuksi, sillä se paransi ruoan tarpeen kokonaismäärän arviointia ja tehosti siten toimintaa. Ajanvaraus myös karsi asiakasmääriä. Yksi vastuuhenkilö kuvasi, että "ajanvaraussysteemi hiukan seuloo asiakkaita, mikä on hyväkin asia. Toiveeni on, että ruokaa hakisivat nimenomaan ne, jotka sitä todella tarvitsevat!”(V17.6.) Järjestöjen edustajien vastauksissa nousi esiin myös esitys asiakaskunnan jakamisesta alueittain niin, että tietyn alueen asiakkaat hakisivat ruoka-apunsa tietystä paikasta, mikä tehostaisi toimintaa ja tasaisi eri ruoka-avun jakajien avustustaakkaa.

Toinen tehokkuutta edistänyt muutos oli valmiiden ruokakassien jakaminen sen sijaan, että asiakkaat itse koostivat oman kassinsa saatavilla olevista tuotteista. Järjestöjen edustajien vastauksissa tämän nähtiin tehokkuuden lisäksi lisäävän tasa-arvoa asiakkaiden välillä, kun ruoan hakemisen järjestys ei 
vaikuttanut saadun ruoan määrään tai laatuun (vrt. Salonen, 2017a). Toisaalta vastaajat esittivät huolen, että valmis kassi kavensi ruoka-avun asiakkaiden valinnanvapautta. Yksi vastuuhenkilö esittääkin toiveen siirtymisestä ruoanjakoon, joka vastaisi enemmän arkista kaupassakäyntikokemusta:

Ruoka-aputoiminnan laadun kehittäminen on tärkeää, eettinen auttamistyö. Pienillä ideoilla ja satsauksilla avun hakemisesta voisi tehdä kuin kaupassa käynnin, eikä se olisi niin nöyryyttävää, jota monet kokevat. (V17.2.)

Myös käytännön toteuttajien ryhmässä ruoan valinnan mahdollisuus jakoi vastaajia: toisaalta tunnistettiin valmiiden kassien tehokkuus, turvallisuus ja tasapuolisuus, toisaalta korostettiin asiakkaan mahdollisuutta valinta ruokansa. Yksi käytännön toteuttaja kuvasi valmiit kassit erityisesti kriisiajan ratkaisuksi: "Tämmöinen toiminta toimii tämmöisinä aikoina mutta muuten olisi kiva et asiakas saa itse valita tuotteet mitä minäkin päivänä haluaa syödä, eikä ole kassiin valmiiksi kaikki laitettuna” (K30.5).

Jotkut ruoka-apujärjestöjen vastuuhenkilöt ottivat esiin myös tasapuolisuuden haasteet eri järjestöjen asiakkaiden välillä. Nämä vastaajat kokivat haasteellisena, että eri toimijoilla oli hieman erilainen tapa jakaa kasseja: joissakin järjestöissä asiakas saattoi saada useita ruokakasseja, kun taas jotkut järjestöt joutuivat pienentämään jaettavia kasseja, jotta ne riittäisivät useammalle asiakkaalle. Tähän ratkaisuna nähtiin yhteiset pelisäännöt järjestöjen välillä sekä asiakaskunnan jakaminen järjestöjen kesken alueittain. Vastuuhenkilö kuvaa ongelmia ja mahdollisia ratkaisuja:

Suurimmat ongelmat ovat mielestäni liittyneet hävikkiruoan saatavuuteen tai myös siihen, että eri alueilla toimivat jakajat voivat toisaalla joutua heittämään ruokaa bioroskiksiin ja toisella alueella ruoka loppuu kesken ja osalle hakijoista pitää sanoa, ettei ole ruokaa. Asiaan ei ole löytynyt ratkaisua. Tavoitteena pitäisi mielestäni olla se, että kullakin alueella olisi riittävästi hävikkiruokaa tarjolla niin, ettei hakijoiden tarvitsisi liikkua alueelta toiselle hakemaan ruokaa. Hakijoita voisi mielestäni ohjata hakemaan ruokaa oman alueen jakopisteistä, jos niitä on. (V13.7.)

Tämän kysymyksen kautta yhteistyön tarve ja avun käytännön organisoinnin muutostarpeet kietoutuvat yhteen. Kuten tuloksista käy ilmi, ruoka-aputoi- 
mintaan toivotaan tiivistyvää yhteistyötä, mikä puolestaan nostaa esiin tarpeita yhdenmukaistaa ja normittaa toimintaa. Ajatusta voi lähestyä myös toisin päin: yhdenmukaisuuden ja tasavertaisuuden vaade ajaa peräänkuuluttamaan tiiviimpää yhteistyötä. Toisaalta, kuten eri toimijoiden rooleja koskevassa osiossa kävi ilmi, ruoka-apua jakavien järjestöjen kenttä on moninainen, ja tämän moninaisuuden mukanaan tuomaa joustavuutta ja ketteryyttä myös kiitetään. Kysymykseksi nousee, kuinka tiivistyvä yhteistyö ja yhdenmukaistamisen paine sovitetaan yhteen jouston ja ketteryyden kanssa.

Lisäksi yhdenmukaistaminen herättää kysymyksen ruoka-avun kyvystä vastata vastaanottajien tarpeisiin. Ei ole itsestään selvää, onko ruoka-apukäytäntöjen yhdenmukaistaminen aina toivottavaa asiakkaiden näkökulmasta. On mahdollista, että yhdenmukaistamisen myötä tämän tutkimuksen vastaajien peräänkuuluttama ketteryys häviää ja ruoka-avusta tulee asiakkaalle virasto muiden joukossa. Ruoka-avun asiakkaat ovat heterogeeninen joukko, ja se mikä sopii yhdelle, ei välttämättä sovi toiselle. Valmiisiin kasseihin ja valinnanvapauteen liittyvä esimerkki paljastaa, että ruoka-avun edelleen kehittämisessä toiminnan tehostamis- ja yhdenmukaistamispyrkimykset sekä asiakkaan toiveet ja tarve voivat asettua keskenään jännitteiseen asemaan. Tästä huolimatta pelisääntöjen ja normien näkyväksi tekeminen on tärkeää: avoimuus, määrittelemättömyys ja matalat rakenteet voidaan nähdä arvoiksi ja tavoiksi rakentaa toimijuuden tilaa, mutta ne voivat myös häivyttää olemassa olevia valtarakenteita näkyvistä ja normalisoida ne kritiikin saavuttamattomiin (Giraud, 2019:179).

\section{Ruoka-apu, yhteistyö ja arvokeskustelu}

Kansainvälisessä tutkimuksessa on havaittu, että aineellista apua tarjoavat toimijat kuvaavat työtään paitsi reaktiona kohtaamaansa hätään, myös tapana osallistua yhteisön toimintaan tuoden esiin toivon ja ihmisarvon näkökulmia. Lisäksi monille on tärkeää herättää keskustelua köyhyydestä ja sen syistä sekä toimia kriittisenä äänenä peräänkuuluttaen julkisen vallan ensisijaista vastuuta heikossa asemassa olevien ihmisten auttamisesta (Noordegraaf, 2010; Salonen, 2016). Ruoka-apuun liittyy Suomessakin yhteiskunnallisia jännitteitä, eikä toimijoiden parissa ole suinkaan aina ollut jaettua näkemystä siitä, onko ruoka-apu julkisen avun paikkaaja vai voiko sitä ajatella yhteiskunnallisena kannanottona ja tapana herättää tietoisuutta ja kriittistä keskustelua köyhyydestä (Heikkilä \& Karjalainen, 2000:246-247). Tässä osiossa tarkastelemme, 
millaisia ruoka-apuun liittyviä arvonäkökohtia nousi esiin tässä tutkimuksessa eri vastaajaryhmien näkökulmasta. Kaupungin poikkeusolojen ruokahuoltoryhmän ja ruoka-apujärjestöjen vastuuhenkilöiden vastauksissa korostuvat hätään vastaamisen ja välittämisen näkökulmat, kun taas ruoka-avun käytännön toteuttajat tuovat esiin vivahteikkaampia ja kriittisempiä näkökulmia.

Kaupungin poikkeusolojen ruokahuoltoryhmään kuuluneiden vastaajien näkökulmasta ruoka-avussa oli kyse välttämättömän huoltovarmuuden turvaamisesta. Kaupunki toimitti lainmukaista tehtäväänsä turvaamalla ruoan saatavuuden kriisissä. Lisäksi kaupungin edustajien joukossa tuli esiin näkemys ruoka-avusta välittämisen osoituksena. Heistä yhden sanoin "ruoka-apu on konkreettista välittämistä ja huolehtimista, ketään espoolaista ei jätetä kriisin hetkellä yksi ilman apua” (R17.10).

Järjestöjen vastuuhenkilöt korostivat yhteiskunnan heikoimmassa asemassa olevien tukemista. Yksi heistä esimerkiksi toteaa, että "Ruoka-avulla on ollut aina suuri merkitys alueen heikoimmassa asemassa oleville"(V16.1). Vastaus kertoo ymmärryksestä ruoka-avun vakiintuneesta luonteesta: Vaikka toteamus, että ruoka-avulla on aina ollut suuri merkitys viittaa historiassa taaksepäin, voidaan sen tulkita sisältävän implisiittisesti ajatuksen ruoka-avun tarpeesta ja järjestöjen roolista tähän tarpeeseen vastaamisesta myös jatkossa.

Kaupungin ja ruoka-avun vastuuhenkilöiden vastauksissa ei tullut juurikaan esiin ruoka-avun olemassaolon kyseenalaistavia kriittisiä näkökulmia. Yksi vastuuhenkilö tosin huomautti, että perusturvan tason nosto vähentäisi ruoka-avun merkitystä:

Normaalitilassakin kolmannen sektorin tarjoama ruoka-apu on monille ihan elintärkeä. Esim pieneläkeläisten tilanne ei helpota, vaan samalla pikku eläkkeellä joutuu kituuttamaan loppuun asti. Koronakriisi on tuonut asiakkaiksi myös henkilöitä, jotka eivät koskaan kuvitelleetkaan joutuvansa asioimaan ruoka-avun piirissä. Toki ruoka-avun merkitys olisi pienempi, jos perustoimeentuloa voitaisiin poliittisin toimienpitein nostaa. Se tietysti olisi kuntien velvollisuuskin, huolehtia siis asukkaidensa perustoimeentulosta. (V16.1.)

Tämä vastaus ottaa huomioon ruoka-avun paikkaavan ja täydentävän roolin suhteessa julkisen sektorin tarjoamaan toimeentulon turvaan. Toisaalta vastaaja näkee ruoka-avun sopeutumiskeinona vallitsevaan, pysyvältä vaikutta- 
vaan tilanteeseen, eikä peräänkuuluta ruoka-apujärjestöjen roolia tilanteen muuttamisessa.

Ruoka-avun käytännön toteuttajat nostivat vastauksissaan esiin muita vastaajaryhmiä laajempia inhimillisiä ja yhteiskunnallisia näkökulmia. Heidän vastauksensa heijastavat ruoka-avun arjesta nousevaa, osin käytännöllistä, osin yhteiskuntakriittistä näkökulmaa. Vastauksissa todettiin ensinnäkin ruoan perustavanlaatuinen merkitys ihmisten elämässä: "Ruoka-apu on tärkeää. Ihmisillä pitää olla syötävää.” (K29.12.) Ruoka-avulla on vastaajien mukaan suuri merkitys vähävaraisille, velkaantuneille ja muissa taloudellisissa vaikeuksissa oleville ihmisille. Yksinäisille ihmisille ruoka-aputoimintaan osallistuminen tarjoaa myös seuraa. Nämä monelle jo ennestään tutut tarpeet korostuivat ja kasvoivat entisestään koronakriisin myötä.

Ruoka-avun käytännön toteuttajat kertoivat vastauksissaan havahtuneensa avustustyön ja koronakriisin myötä ruoka-avun tarpeen todellisuuteen ja määrään. He nostivat esiin huomioita avun resurssien tarpeesta ja pohtivat huolta kantaen, kuinka resurssit ja yhteistyön mahdollisuudet turvataan koronakriisin jälkeen. Vastaajat peräänkuuluttivat valtiolta parempaa valmiutta vastata kriiseihin. Toisaalta he pohtivat myös epävarmuuden keskellä selviämisen merkitystä. Ruoka-avun käytännön toteuttajat kertoivat kriisiajan ruoka-avun kasvattaneen heidän ymmärrystään inhimillisyyden, pyyteettömyyden ja lähimmäisenrakkauden merkityksestä. He kertoivat myös huomanneensa ruoka-aputyön kautta, ettei kaikkea voi mitata tehokkuuteen perustuvilla mittareilla. Yksi käytännön toteuttajista vastasi ponnekkaasti:

Kapitalismi on tullut tiensä päähän. Kaikkea ei voi mitata talouskasvulla tai työpaikkojen määrällä. Verotusta nostamalla pitää rakentaa valtio, joka on valmis kohtaamaan kriisin kuin kriisin niin että köyhiä ja muita apua tarvitsevia on mahdollista suojella. (K31.16.)

Käytännön ruoka-aputyötä tekevät vastaajat kuvasivat, kuinka olivat havahtuneet kaupallisuuden keskeisyyteen ja hävikin määrään yhteiskunnassa. Yksi heistä peräänkuulutti laajempaa tietoisuutta hävikin määrästä:

Moni varmasti pohtii kauppojen hävikkiruokamääriä, muttei tiedä siitä mitään tai kuinka paljon sitä todella päätyy kaatopaikoille; ihmisten tulisi olla tietoisempia heidän valinnoistaan. (K30.40.) 
Käytännön avustustyötä tekevät henkilöt esittivät ruokahävikkiin liittyen myös vaatimuksia ruokaa lahjoittaville tahoille. He peräänkuuluttivat erityisesti ruoan laadun parempaa huomioimista. Avun saajan tarpeet ja ruoan terveellisyys ja ravitsevuus tulisi ottaa jatkossa paremmin huomioon. Ruokaa lahjoittavien tahojen tulisi myös osallistua käytännön työhön enemmän karsimalla itse huonot tuotteet roskiin. Tähän liittyen terävän kriittisen huomion esitti myös vastuuhenkilö, jonka mukaan "Biojätteen määrä oli uskomaton, kaupat tuntuivat pitävän meitä biojäteastioina" (V6.10). Näin myös hävikkiruoan lahjoittajia vastuutettiin tiiviimpään yhteistyöhön ja toimintatapojen kehittämiseen.

Keskeinen ruoka-avun ongelma liittyy ruoan kysynnän ja tarjonnan välisiin epäjatkuvuuksiin. Koska ruoka-apu perustuu hävikkiin, se ei läheskään aina vastaa avunsaajien tarpeisiin. Ruoka-aputoimijat heittävät suuret märät lahjoitusruokaa pois, koska se todetaan jo käsittelyvaiheessa syömäkelvottomaksi. Hävikkiin perustuva ruoka-apu on osa hyväntekeväisyystaloutta ( $\mathrm{Sa}-$ lonen \& Silvasti, 2019), joka tulkitsee uudelleen hävikin yhteiskunnallisen ongelman sijaan resurssiksi. Myös tässä tutkimuksessa hävikki nähtiin näitä muutamia kriittisiä huomioita lukuun ottamatta ruoka-avun resurssina. Tulosten perusteella elintarvikejärjestelmän toimijoiden rooliin ruoka-avun kentällä tulisikin jatkossa kiinnittää enemmän huomiota. Ne ovat avainasemassa, kun kysytään, kuinka järjestää ruoka-apu niin, että se ottaa paremmin huomioon ruoan saatavuuden, riittävyyden ja laadun sekä terveellisyyden, ravitsevuuden ja asiakkaiden erilaiset ruokavaliot ja toiveet.

\section{Pohdinta ja johtopäätökset}

Tässä tutkimuksessa olemme tarkastelleet ruoka-apua ja siihen liittyvää yhteistyötä koronakriisissä toimijoiden roolien, toiminnan muutostarpeiden ja arvokysymysten näkökulmista. Tutkimuksemme tuottaa merkittävää ja ajankohtaista uutta tietoa ruoka-avusta, erityisesti sektorien välisen yhteistyön mahdollisuuksista ja reunaehdoista. Tulokset valottavat myös laajemmin ruoka-avun vakiintumiskertomusta. Ruoka-apu ei näytä olevan häviämässä. Saksalaisen sosiologin Stephen Lorenzin (2012:386) sanoja mukaillen ruoka-apu on otettava huomioon uutena yhteiskunnissamme vallitsevana sosiaalisena faktana.

Ruoka-avun kentällä toimivat järjestöt ja kaupungin toimijat jakoivat melko yhdenmukaiset käsitykset omasta ja toistensa roolista ruoka-avussa. 
Tätä roolitusta kuvaa ennemmin kumppanuus (tai joissakin tapauksissa erillisyys ja itsenäisyys), kuin vastakkaisuus tai jännitteisyys. Ruoka-apu nähdään vastauksissa jännitteisen yhteiskunnallisen ongelman sijaan sosiaalisena innovaationa (Salonen, 2018), jossa keskeisiä näkökulmia ovat sektorirajat ylittävät, uudet yhteistoiminnan muodot ja logististen kysymysten ensisijaisuus politiikkaan nähden. Eri sektorien toimijoiden väliset suhteet eivät kuitenkaan ole ruoka-avussa täysin tasavertaisia. Kaupungilla on päätäntävaltaa määrittää yhteistoiminnan reunaehtoja yksittäisiä järjestöjä enemmän. Järjestöjen kannalta keskeiseksi nouseekin punnita, kokevatko he hyötyvänsä enemmän siitä, että saavat yhteistyössä synergiaetuja ja äänensä paremmin kuuluviin, vai siitä, että voivat itsenäisinä toimijoina tehdä autonomisia ratkaisuja ja toteuttaa työtään itse parhaaksi katsomallaan tavalla.

Tulokset tuovat lisäksi esiin ruoka-avun kenttää koskevia muutostarpeita. Keskeiset muutostarpeet liittyvät yhteistyön tiivistämiseen ja vakiinnuttamiseen sekä ruoka-avun toimintatapojen kehittämiseen yhdenmukaisempaan suuntaan. Ruoka-avun tiivistyvä yhteistyö on osa ruoka-avun vakiintumiskehitystä, jossa toiminta nähdään entistä vahvemmin väliaikaisen hätäavun sijaan pysyvänä osana sosiaalisiin ja taloudellisiin ongelmiin vastaamisen keinovalikoimaa. Vakiintuminen ja siihen liittyvä yhteistyö näyttävät tuovan mukanaan paineen yhdenmukaista ruoanjaon käytänteitä. Toimijoiden arvioitavaksi jää, mitä näkökulmia yhdenmukaistamisessa otetaan huomioon: Painotetaanko toiminnan tehokkuutta järjestäjien näkökulmasta vaiko avun saajien tasapuolista kohtelua tai valinnanvapautta.

Ruoka-apukentän muutos on paitsi käytännöllinen, myös arvoihin liittyvä kysymys. Yhdenmukaistamista peräänkuulutettiin paitsi toiminnan tehostamisen, myös asiakkaiden tasapuolisen kohtelun näkökulmasta. Ruoka-apua on perinteisesti pidetty lahjan ja vapaaehtoisen auttamisen piiriin kuuluvana toimintana (Silvasti, 2015:480). Diakoniatyön tutkimuksessa on kuitenkin löydetty heikko signaali, jossa diakonia-apu on alettu käsittää julkiseen hyvinvointipalveluun rinnastettavaksi oikeudeksi (Malkavaara \& Ryökäs, 2015:122-123). Tästä tutkimuksesta voidaan havaita samansuuntainen heikko signaali: ruoka-avunkin kenttää näyttää valtavan ajatus, että apu on oikeus, jonka tulisi jakautua tasapuolisesti kaikille.

Aiemmissa tutkimuksissa ruoka-apujärjestöt on nähty suhteessa julkisen sektorin toimijoihin yhteistyökumppanien lisäksi arvokeskustelijoina, jotka kritisoivat yhteiskunnan epäkohtia. Tässä tutkimuksessa tämä näkökulma ei 
tullut korostetusti esiin. Laajimmin yhteiskunnallisia epäkohtia ottivat esiin ruoka-avun käytännön toimijat, kun taas kaupungin edustajien vastauksissa korostui välittäminen ja lainmukaisten tehtävien hoitaminen ja ruoka-apujärjestöjen vastuuhenkilöiden vastauksissa ruoka-avun vakiintumisen hyväksyntää heijastava auttamisen välttämättömyys. Tulokset herättävät pohtimaan, missä ja kenen toimesta ruoka-apuun liittyvää kriittistä yhteiskunnallista arvokeskustelua käydään tulevaisuudessa yhteistyön mahdollisesti tiivistyessä: Voivatko järjestöjen vastuuhenkilöt esittää avointa kritiikkiä perusturvaa ja palvelujärjestelmän aukkoja kohtaan samalla, kun ne toimivat julkisen sektorin kanssa yhä tiiviimmässä kumppanuussuhteessa vai vähentääkö yhteistyö kansalaisyhteiskunnan toimijoiden pelivaraa kriittisinä ääninä? Entä tuleeko käytännön työn toteuttajien yhteiskunnallisia epäkohtia esiin nostava ääni kuuluviin ruoka-avun toteuttamisesta päättävien ihmisten pöydissä?

Lisäksi tulokset herättävät pohtimaan vakiintuvan ruoka-avun tarkoitusta. On huomionarvoista, että vastauksissa ei kyseenalaisteta ruoan keskeisyyttä auttamisen tapana, vaikka esimerkiksi kaupungin edustajien näkemyksissä tuli ilmi, että koronakassin osalta keskeistä ei ollut niinkään ruoan tarve, kuin tarve muiden palveluiden piiriin ohjaamiseen. Ruoka on monelle ruoka-avun saajalle tärkeä apu, mutta palvelujärjestelmän kokonaisuuden ja kehittämisen kannalta keskeistä on myös ruoka-avun käytännön toiminnasta saatava tieto. Ruoka-avulla on paitsi funktionaalinen, myös performatiivinen rooli: se artikuloi yhteiskunnan tilaa ja kaikkein heikoimmassa asemassa olevien tilannetta. Sen kautta voidaan tarkastella näiden ihmisten avun tarpeita. Keskeistä on, että julkinen palvelujärjestelmä ottaa tämän tiedon vakavasti ja etsii sen avulla keinoja vastata ihmisten tarpeisiin entistä paremmin.

Tulosten tulkinnassa on otettava huomioon aineiston asettamat rajoitukset. Aineiston näkökulmana on ruoka-avun kentällä toimivien tahojen itsensä sanoittama kokemus, jonka taustana on koronakriisin aiheuttama akuutti murrostilanne. Olemme pidättäytyneet analyysissä tulkitsemaan näitä kokemuksia, emmekä tutkineet toimintaa käytännössä esimerkiksi kenttähavainnoinnin keinoin. Lisäksi lomakekyselyssä vastaukset ovat verrattain lyhyitä, ja monet yksityiskohdat jäävät vaille perusteluita ja taustoitusta. Syventävät haastattelut ja toiminnan yksityiskohtaisempi analyysi sekä vertailevat asetelmat ovat tarpeen tulevaisuudessa, jotta aihepiiristä saadaan yhä kattavampaa tietoa. Esimerkiksi arvokeskustelua koskevien tulosten tulkinnassa on otettava huomioon, että tiivistyvän yhteistyön lisäksi akuutti koronakriisi on 
mahdollisesti korostanut tarvetta samassa veneessä olemista korostavalle yhteistyöpuheelle. Jatkotutkimuksen aiheeksi jää, heijastaako tulos lopulta vakiintumista ja yhteistyötä vai vallinnutta akuuttia kriisiä.

\section{Viite}

1 Tässä artikkelissa viittaamme ruokaapua jakaviin yhteisöihin järjestökentän toimijoina. Vaikka evankelisluterilaisen kirkon asema ei viranomaistehtäviensä ja lainsäädännöllisen asemansa vuoksi

\section{Kirjallisuus}

Alasuutari, P. (2011). Laadullinen tutkimus 2.0. Tampere: Vastapaino.

Alppivuori, K. (2021). Mitä kertovat ruoka-apua hakevat ihmiset. Espoolainen ruoka-apu, avun tarve ja palvelukokemukset ruoka-avun hakijoiden näkökulmasta. Espoo: Espoon kaupunki. https://www. espoo.fi/fi-FI/Espoon_kaupunki/Tietoa_ Espoosta/Julkaisut (Sosiaali- ja terveystoimen julkaisut - Muut julkaisut - Mitä kertovat ruoka-apua hakevat ihmiset. Espoolainen ruoka-apu, avun tarve ja palvelukokemukset ruoka-avun hakijoiden näkökulmasta) - Viitattu 25.5.2021.

Alppivuori, K. (2020). Espoolaisen ruoka-avun toteutuminen ja muutos koronakriisin aikana keväällä 2020. Espoo: Espoon kaupunki https://www.espoo.fi/fi-FI/Espoon_kaupunki/Tietoa_Espoosta/Julkaisut (Sosiaali- ja terveystoimen julkaisut - Raportit - Espoolaisen ruoka-avun toteutuminen ja muutos koronakriisin aikana keväällä 2020) - Viitattu 25.5.2021.

Alppivuori, K. (2019). Espoon kasvu maalaiskunnasta kaupungiksi. Sosiaalipalvelujen kehitys toiminnoittain vuosina 1929-1995. Espoo: Espoon kaupunki. https://www. espoo.fi/fi-FI/Espoon_kaupunki/Tietoa_ Espoosta/Julkaisut https://www.espoo. fi/fi-FI/Espoon_kaupunki/Tietoa_Es- palaudu yksioikoisesti kolmannen sektorin tai järjestökentän toimintaan, voidaan se diakonisen ja sosiaalityönsä osalta katsoa kansalaisyhteiskunnan toimijaksi (Karjalainen, 2000:268-269).

poosta/Julkaisut (Sosiaali- ja terveystoimen julkaisut - Historia - Sosiaalitoimen kehitys Espoossa 1929-1995) - Viitattu 25.5.2021.

Giraud, E. (2019). What Comes after Entanglement? Activism, Anthropocentrism, and an Ethics of Exclusion. Durham: Duke University Press. https://doi. org/10.1215/9781478007159

Hiilamo, H. (2012). Rethinking the role of church in a socio-democratic welfare state. The International Journal of Sociology and Social Policy, 32(7), 401-414. https://doi. org/10.1108/01443331211249048

Heikkilä, M., \& Karjalainen, J. (2000). Vuotoja hyvinvointivaltion turvaverkossa - kansalaiskeskustelun merkitys suomalaisessa hyvinvointipolitiikassa. - M. Heikkilä, J. Karjalainen \& M. Malkavaara (toim.), Kirkonkirjat Köyhyydestä. Helsinki: Kirkkopalvelut, 212-266.

Iivari, J. \& Karjalainen, J. (1999). Diakonian köyhät. Epävirallinen apu perusturvan paikkaajana. Stakes: Helsinki, Finland.

Juntunen, E., Grönlund, H. \& Hiilamo, H. (2006). Viimeisellä luukulla. Tutkimus viimesijaisen sosiaaliturvan aukoista ja diakoniatyön kohdentumisesta. Kirkkohallitus: Helsinki.

Kallunki, V. (2010). Yhteisön ja ybteiskunnan 
ebdoilla. Seurakuntien ja kuntien ybteistyö vuorovaikutuksen näkökulmasta. Helsinki: Helsingin yliopisto.

Karjalainen, J. (2000). Ruokapankkien paikallinen vaikuttavuus. - M. Heikkilä, J. Karjalainen \& M. Malkavaara (toim.), Kirkonkirjat köyhyydestä. Helsinki: Kirkkopalvelut, 267-287.

Karjalainen, J. (2008). Nälkä-äläkästä nälkäryhmään. Tutkimus, ruokapankit ja politiikka lehdistössä. - S. Hänninen, J. Karjalainen, K. Lehtelä \& T. Silvasti (toim.), Toisten Pankki. Ruoka-apu Hyvinvointivaltiossa. Helsinki: Stakes, 69-114.

Karjalainen, J., Hossain-Karhu, R., Marjamäki, P. \& Sinkkonen, A. (2021). Ruoka luo ybteyden. Ruoka-apu hyvinvointivaltiossa. Helsinki: Pääkaupunkiseudun sosiaalialan osaamiskeskus Socca.

Laihiala,T. \& Ohisalo,M.(2017). Sosiaalipummit leipäjonossa? Kansalaisten käsityksiä huono-osaisten ansaitsevuudesta. - J. Saari (toim.), Sosiaaliturvariippuvuus. Sosiaalipummit Oleskeluyhteiskunnassa? Tampere: Tampere University Press, 233-258.

Lambek, M. (toim.) (2010). Ordinary Ethics. Anthropology, Language, and Action. New York: Fordham University Press.

Lehtinen, S. (2013). Julkisen sektorin apulaiset, kansalaisybteiskunnan talkoolaiset: Suomen evankelis-luterilaiset seurakunnat Euroopan sosiaalirahaston projekteissa. Helsinki: Helsingin yliopisto.

Loopstra, R., \& Tarasuk, V. (2012). The relationship between food banks and household food insecurity among low-income Toronto families. Canadian Public Policy, 28(4), 497-514. https://doi.org/10.3138/ CPP.38.4.497

Loopstra, R. \& Tarasuk, V. (2015). Food bank usage is a poor indicator of food insecurity: Insights from Canada. Social Policy and Society, 14, 443-455. https://doi. org/10.1017/S1474746415000184

Lorenz, S. (2012). Socio-ecological consequences of charitable food assistance in the affluent society: The German Tafel. The International Journal of Sociology and Social Policy, 32(7/8), 386-400. https://doi. org/10.1108/01443331211249011

MacLeod, M. (2018). Understanding the Rise of Food Aid and Its Implications for the Welfare State: A study of Scotland and Finland. Glasgow: University of Glasgow.

Malkavaara, M., \& Ryökäs, E. (2015). Diakonia-apu oikeutena - suomalaisen ajattelutavan kehittyminen. Diakonian Tutkimus, (2), 107-127.

Noordegraaf, H. (2010). Aid under protest? Churches in the Netherlands and material aid to the poor. Diaconia. Journal for the Study of Christian Social Practice, 1(1),47-61.https://doi.org/10.13109/diac. 2010.1.1.47

Ohisalo, M., Eskelinen, N., Laine, J., Kainulainen, S., \& Saari, J. (2013). Avun tilkkutäkki. Suomalaisen ruoka-apukentän monimuotoisuus. Helsinki: RAY.

Ohisalo, M. (2017). Murusia hyvinvointivaltion pohjalla: Leipäjonot, koettu hyvinvointi ja huono-osaisuus. Ph.D. Kuopio: ItäSuomen yliopisto.

Poppendieck, J. (1999). Sweet Charity? Emergency Food and the End of Entitlement. New York: Penguin Books.

Riches, G. (2002). Food banks and food security: Welfare reform, human rights and social policy. Lessons from Canada? Social Policy and Administration, 36(6), 648-663. https://doi.org/10.1111/14679515.00309

Riches, G. (toim.) (1997). First World Hunger. Food Security and Welfare Politics. London: Macmillan. https://doi. org/10.3138/9781442602595

Riches, G. \& Silvasti, T. (toim.) (2014). First World Hunger Revisited. Food Charity or The Right to Food? 2. painos. Palgrave Macmillan: Basingstoke. https://doi. org/10.1057/9781137298737

Salonen, A. S. (2016). Lifelong Emergency? The food bank in an era of institutionalized food charity in Toronto. Diaconia. The Journal for the Study of Christian Social Practice, 7(1), 27-42. https://doi. org/10.13109/diac.2016.7.1.27

Salonen, A. S. (2017a). Lining up for charity. A study of the social organization 
and communal qualities of breadlines in a Finnish city. The International Journal of Sociology and Social Policy, 37(3/4), 218-230. https://doi.org/10.1108/ IJSSP-10-2015-0110

Salonen, A. S. (2017b). Ruoka-avun institutionalisoituminen ja uskonnon paikka: Suomen ja Kanadan vertailua. Diakonian tutkimus, 2, 43-61.

Salonen, A. S. (2018). Religion, poverty and abundance. A research comment. Palgrave communications special issue: Religion and Poverty. Palgrave Communications, 4, 27. https://doi.org/10.1057/s41599-0180086-8

Salonen, A. S., Silvasti, T. (2019). Faith-based organizations as actors in the charity economy: A case study of food assistance in Finland. - H. Gaisbauer, G. Schweiger \& C. Sedmak (toim.), Absolute Poverty in Europe. Interdisciplinary Perspectives on a Hidden Phenomenon. Bristol: Policy Press. https://doi.org/10.1332/policypress/9781447341284.003.0013

Salonen, A. S., Ohisalo, M. \& Laihiala, T. (2018). Undeserving, disadvantaged, disregarded: Three viewpoints of charity food aid recipients in Finland. International Journal of Environmental Research and Public Health, 15(12), 2896. https:// doi.org/10.3390/ijerph15122896
Sayer, A. (2011). Why Things Matter to People: Social Science, Values and Ethical Life. Cambridge: Cambridge University Press.

Silvasti, T. (2011). Ruoka-avun vakiinnuttaminen Suomessa. Tarpeen ja oikeutuksen jäljillä. Janus, 19(3), 279-289.

Silvasti, T. (2015). Food aid - normalising the abnormal in Finland. Social Policy and Society, 14(3), 471. https://doi.org/10.1017/ S1474746415000123

Silvasti, T., \& Karjalainen, J. (2014). Hunger in a Nordic welfare state: Finland. - G. Riches, \& T. Silvasti (toim.), First World Hunger Revisited. Food Charity or the Right to Food? 2. painos. Basingstoke: Palgrave Macmillan, 72-86. https://doi. org/10.1057/9781137298737_6

Sosiaalibarometri (2020). Sosiaalibarometri 2020. SOSTE Suomen sosiaali ja terveys ry. Helsinki: SOSTE. https://www.soste. fi/wp-content/uploads/2020/07/SOSTE-Sosiaalibarometri-2020.pdf - Viitattu 2.12.2020.

Tikka, V. (2019). Charitable food aid in Finland: from a social issue to an environmental solution. Agriculture and Human Values, 36(2), 341-352. https://doi.org/10.1007/ s10460-019-09916-3

Tuomi, J. \& Sarajärvi, A. (2018). Laadullinen tutkimus ja sisällönanalyysi. Uudistettu laitos. Helsinki: Tammi. 